\title{
DOES CORRUPTION INHIBIT FOREIGN DIRECT INVESTMENT?
}

Conceição Castro (conceicaocastro@eu.ipp.pt)

School of Industrial and Management Studies of Polytechnic Institute of Porto, Portugal

Pedro Nunes (pnunes@ipca.pt)

School of Management at the Polytechnic Institute of Cávado e Ave, Portugal.

Globalization creates new opportunities for firms to invest abroad and many economies are making active efforts to attract Foreign Direct Investment (FDI) in order to promote economic growth. Decisions to invest abroad depend on a complex set of factors, but the least corrupt countries may attract more foreign direct investment because they provide a more favorable climate for investors. In this paper we investigate the impact of corruption on FDI inflows in 73 countries, over the period 1998-2008. Our results suggest that countries where corruption is lower, the FDI inflows are greater, and so controlling corruption may be an important strategy for increase FDI inflows.

Keywords: Corruption, Foreign Direct Investment, economic growth.

\section{¿LA CORRUPCIÓN INHIBE LA INVERSIÓN EXTRANJERA DIRECTA?}

La globalización ha creado nuevas oportunidades para invertir en el extranjero y muchas economías están haciendo esfuerzos para atraer inversión extranjera directa (IED) con el fin de promover el crecimiento económico. La decisión de invertir en el extranjero depende de un complejo conjunto de factores. No obstante, los países menos corruptos pueden atraer más inversión extranjera directa, ya que proporcionan un clima más favorable para los inversionistas. En este trabajo se investiga el impacto de la corrupción sobre los flujos de IED en 73 países, en el período 1998-2008. Los resultados sugieren que los países donde la corrupción es menor, las entradas de IED son mayores, por lo que el control de la corrupción puede ser una estrategia importante para aumentar los flujos de IED.

Palabras clave: corrupción, Inversión extranjera directa, crecimiento económico. 


\section{Introduction}

Every country wants to attract Foreign Direct Investment (FDI), because it is expected to have favourable effects on the economy: on income, technology, knowhow, management skills, local market competition, job opportunities, global market, and economic growth. FDI inflows are affected by economic factors such as the size of the economy, its growth rate, but also by its business facilitation and institutional framework. In this sense, corruption may also be considered an important determinant of FDI. Corruption potentially reduces investment (Mauro, 1995; Keefer and Knack, 1996) and, particularly, foreign investment. Uncertainty increases in environments with higher corruption, as does the cost of doing business. Functioning as a tax on business (due to the increase of time and resources spent to deal with complex regulations and bribes to bureaucrats), the cost is often transferred to consumers through higher prices or lower quality of goods and services, which affect negatively the private sector's labour market, efficiency, competition, innovation and, in particular, economic growth. These increased business costs may also cause a shift from part of the economic activity into the informal sector, in order to avoid the use of public services as much as possible.

The working definition of corruption by the World Bank is the abuse of public power for private benefit. Transparency International (1996) adds "corruption involves behavior on the part of officials in the public sector, whether politicians or civil servants, in which they improperly and unlawfully enrich themselves, or those close to them, by the misuse of the public power entrusted to them" (p. 1). Corruption, which can result from one or several factors, such as excessive bureaucracy, high discretion in the formulation and implementation of policies, inefficiency and slowness of the legal system, low wages in the civil service and lower degree of economic freedom, potentially affects many aspects of economy, namely foreign investment and economic growth; and has been a concern for some international organizations such as the World Bank, Transparency International, the International Monetary Fund and the Organisation for Economic Cooperation and Development (OECD). Corruption is a phenomenon that nowadays affects not only developing economies, but also more advanced ones. Through international strategic alliances, mergers and acquisitions, the globalization process has led to new standards in government and business ethics, and corruption creates obstacles to that process, making the control of corruption an increasingly important subject.

Although we acknowledge corruption as a multifaceted phenomenon, it can be regarded as an economic problem, since it has high costs for the private and public sectors in the long run. The purpose of this article is to study the impact of corruption on FDI inflows in a panel of 73 countries, during the period 1998-2008, controlled by economic and political variables. Beside traditional economic variables 
that potentially explain FDI inflows (GDP, economic growth or human capital), we also study the influence of good governance in host countries transparency, but also its effect on government effectiveness and political stability. Beyond these political aspects, the assurance of property rights and the legal framework for doing business may have an important role on the decision to invest abroad, so we also introduce business freedom and rule of law indicators.

This paper is organized as follows: Section 1 describes the major FDI and corruption trends. Section 2 reviews some existing literature on FDI inflows determinants. Section 3 details the empirical model used for estimation, data and samples. Section 4 presents and analyzes the econometric results for FDI and corruption. Section 6 presents our conclusions.

\section{Corruptions and FDI}

Globalization is one of the major trends of the last two decades, and because of that FDI has grown all over the world. As Dunning (2003, p. 279) states: "FDI flows still remain one of the most constitutive elements of the global economy". FDI inflows grew at an annual average of $14.7 \%$ in the 70 's, $19.1 \%$ in the 80 's, $20.8 \%$ in the 90 's and $10 \%$ in the first decade of the 21 st century. In transition economies, although the level of FDI inflow is significantly inferior to the one seen in developing and developed countries, their average annual growth rates are significantly higher in the 80's and 90's (Figure 1).

\section{Figure 1}

FDI inflows: average annual growth (\%) in developed, transition and developing economies

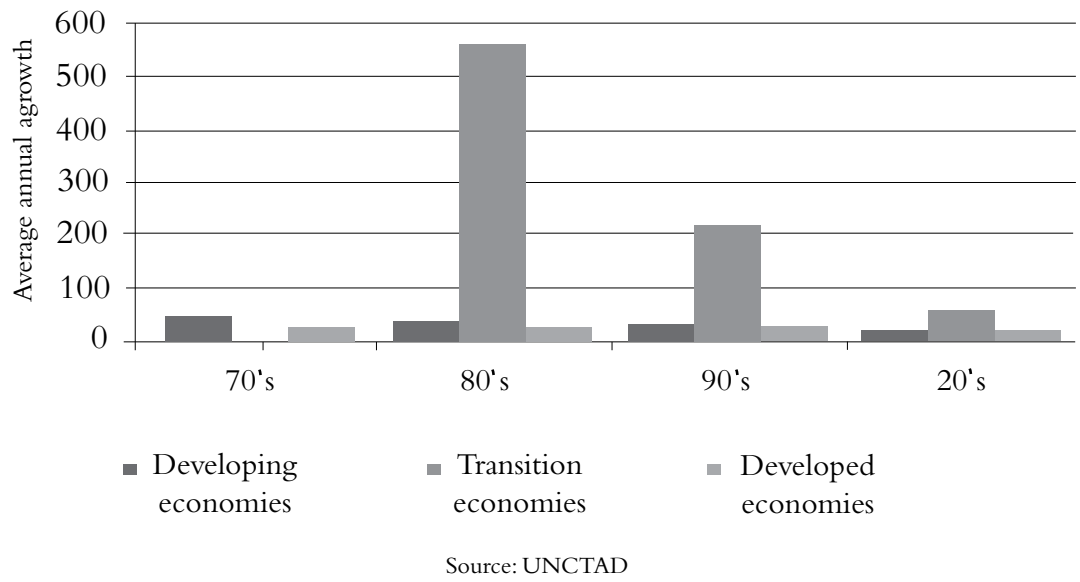


The share of inward and outward FDI stocks (the value of their capital and reserves stock, including retained profits, attributable to the parent company, plus the parent company affiliates net indebtedness) grew from 12,2\% of the GDP in 1980 to 48,6\% in 2000, and 63,3\% in 2009 (Table 1). The world FDI stock is ten times more in 2008 than it was in 1990 (Figure 2).

Table 1

Inward and Outward FDI stocks \% of GDP, selected years

\begin{tabular}{|c|c|c|c|c|c|c|c|c|c|c|}
\cline { 2 - 12 } \multicolumn{1}{c|}{} & \multicolumn{2}{c|}{1980} & \multicolumn{2}{c|}{1985} & \multicolumn{2}{c|}{1990} & \multicolumn{2}{c|}{1995} & \multicolumn{2}{c|}{2000} \\
\cline { 2 - 12 } \multicolumn{1}{c|}{} & Inward & Outward & Inward & Outward & Inward & Outward & Inward & Outward & Inward & Outward \\
\hline World & 6,6 & 5,6 & 8,4 & 7,7 & 9,4 & 9,9 & 11,4 & 12,3 & 23,4 & 25,2 \\
\hline $\begin{array}{c}\text { Developing } \\
\text { economies }\end{array}$ & 11,6 & 3,6 & 14,6 & 3,5 & 13,3 & 3,8 & 14,3 & 5,7 & 24,8 & 12,7 \\
\hline $\begin{array}{c}\text { Transition } \\
\text { economies }\end{array}$ & n. a. & n. a. & n. a. & n. a. & 0,2 & 0,6 & 2,0 & 0,9 & 15,4 & 5,8 \\
\hline $\begin{array}{c}\text { Developed } \\
\text { economies }\end{array}$ & 5,1 & 6,1 & 6,6 & 8,9 & 9,0 & 11,3 & 10,9 & 14,1 & 23,1 & 28,9 \\
\hline G8 & 4,2 & 6,2 & 5,6 & 8,5 & 7,8 & 10,8 & 9,0 & 13,0 & 20,2 & 27,1 \\
\hline G20 & 4,2 & 5,9 & 5,9 & 7,7 & 7,9 & 9,7 & 9,1 & 11,5 & 19,3 & 23,1 \\
\hline
\end{tabular}

n.a. - not available

\begin{tabular}{|c|c|c|c|c|c|c|c|c|c|c|}
\cline { 2 - 12 } \multicolumn{1}{c|}{} & \multicolumn{2}{c|}{2005} & \multicolumn{2}{c|}{2006} & \multicolumn{2}{c|}{2007} & \multicolumn{2}{c|}{2008} & \multicolumn{2}{c|}{2009} \\
\cline { 2 - 12 } & Inward & Outward & Inward & Outward & Inward & Outward & Inward & Outward & Inward & Outward \\
\hline World & 25,4 & 27,4 & 29,0 & 32,0 & 32,5 & 35,1 & 25,5 & 26,8 & 30,5 & 32,8 \\
\hline $\begin{array}{c}\text { Developing } \\
\text { economies }\end{array}$ & 25,2 & 12,3 & 26,8 & 14,2 & 30,1 & 16,6 & 24,5 & 14,1 & 27,9 & 14,6 \\
\hline $\begin{array}{c}\text { Transition } \\
\text { economies }\end{array}$ & 25,3 & 14,2 & 28,5 & 16,3 & 37,3 & 21,6 & 18,2 & 9,9 & 27,7 & 16,1 \\
\hline $\begin{array}{c}\text { Developed } \\
\text { economies }\end{array}$ & 25,4 & 32,6 & 29,8 & 38,8 & 33,3 & 42,7 & 26,3 & 32,9 & 31,8 & 41,2 \\
\hline G8 & 21,0 & 29,4 & 24,5 & 34,5 & 26,1 & 38,4 & 18,7 & 27,2 & 23,4 & 35,2 \\
\hline G20 & 20,2 & 24,4 & 22,8 & 28,0 & 24,1 & 30,6 & 17,7 & 21,8 & 22,1 & 28,0 \\
\hline
\end{tabular}

Source: UNCTAD 
Figure 2

World FDI stock (inward), US dollars at current prices and current exchange rates in hundred millions, 1980-2008

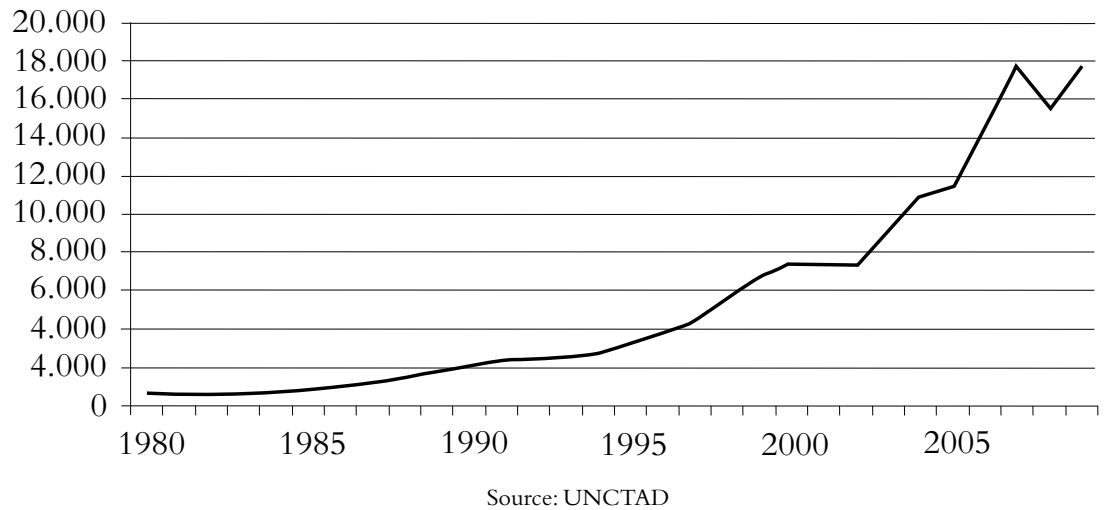

Concerns with corruption have arisen with globalization, since international strategic alliances as mergers and acquisitions depend much more on mutual trust. Differences in business standards, government ethics and regulation make that process more difficult. Traditionally, corruption was a typical phenomenon of underdeveloped or developing countries, but at present the reality is very different. Corruption indicators show large differences between developing economies and emerging economies, but also among the most developed. Corruption is a problem, and constitutes a major challenge even for the richest countries. Therefore, disparity in levels of corruption among the group of the most industrialized and developed countries of the world should be highlighted: Canada is in the top eight of least corrupt countries (amongst a total of 180), Germany in $14^{\text {th }}$, Japan and United Kingdom are tied at the $17^{\text {th }}$ spot, the United States of America is in the $19^{\text {th }}$, France $24^{\text {th }}$, but Italy holds the $63^{\text {rd }}$ position and Russia the $146^{\text {th }}$. When we consider the G20 (which also includes the emerging countries) representing 90\% of world GDP and $80 \%$ of the world trade, differences are greater, with the exemption of Australia (in $8^{\text {th }}$ position): South Korea $\left(39^{\text {th }}\right)$, South Africa $\left(55^{\text {th }}\right)$, Saudi Arabia $\left(63^{\text {rd }}\right)$, Turkey $\left(61^{\text {st }}\right)$, Brazil $\left(75^{\text {th }}\right)$, China $\left(79^{\text {th }}\right)$, India $\left(84^{\text {th }}\right)$, Mexico $\left(89^{\text {th }}\right)$, and Indonesia $\left(111^{\text {th }}\right)$. Among the countries of G20 that are members of the European Union (EU), Nordic countries lead public administration transparency, and some transition and developed economies (Bulgaria, Romania and Greece) show very high levels of corruption (the highest of the EU), placing them in the $71^{\text {st }}$ worldwide position, according to Transparency International. 
Among the $27 \mathrm{EU}$ member states, there are economies in transition like Slovenia, Estonia and Cyprus, which corruption levels are relatively lower than some southern EU-15 countries (Portugal, Spain, Italy and Greece).

Figure 3

Corruption Perception Index, 2009

\begin{tabular}{|c|c|}
\hline 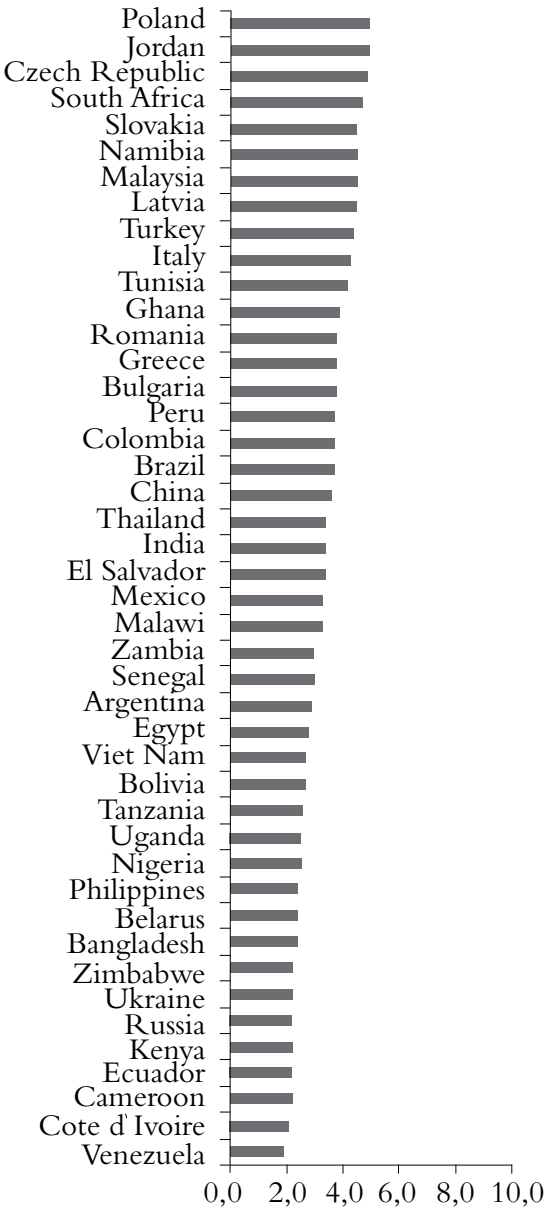 & $\begin{array}{r}\text { New Zeland } \\
\text { Denmark } \\
\text { Sweden } \\
\text { Singapore } \\
\text { Switzerland } \\
\text { Netherlands } \\
\text { Finland } \\
\text { Iceland } \\
\text { Canada } \\
\text { Australia } \\
\text { Norway } \\
\text { Luxembourg } \\
\text { Ireland } \\
\text { Germany } \\
\text { Austria } \\
\text { United Kingdom } \\
\text { Japan } \\
\text { United States } \\
\text { Belgium } \\
\text { Viet Nam } \\
\text { Chile } \\
\text { Estonia } \\
\text { Spain } \\
\text { Israel } \\
\text { Portugal }\end{array}$ \\
\hline
\end{tabular}

Source:Transparency International

Note:Transparency International's Corruption Perception Index ranges from 0 (most corrupt) to 10 (least corrupt), so higher levels actually reflect lower corruption. 
Figure 4 compares FDI inflows in total world percentages and the Corruption Perception Index for 73 countries (this research sample) and shows that countries, which attract more FDI, show low levels of corruption, although China, Brazil, Russia and Italy had in average high levels of corruption and important FDI inflows.

Figure 4

FDI inflows (total world percentages) and Corruption Perception Index, 73 countries (average 1998-2008)

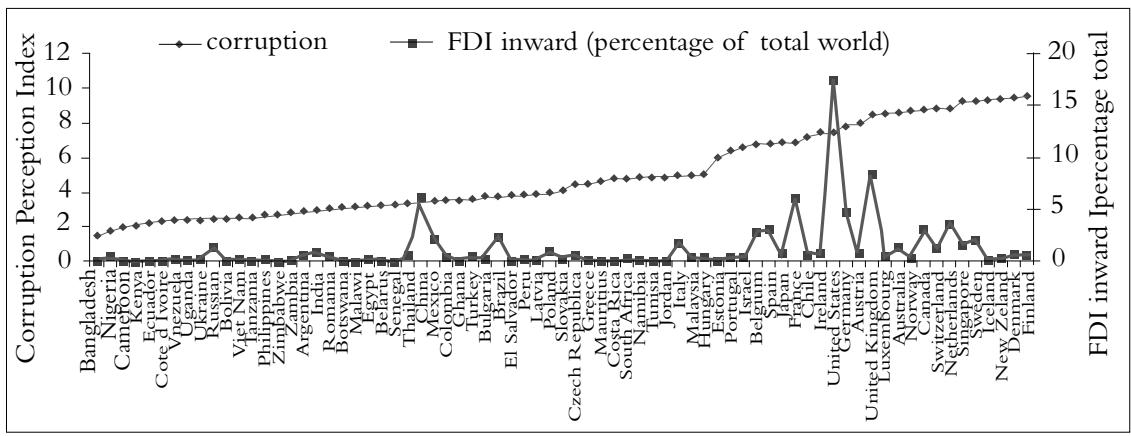

Sources: UNCTAD and Transparency International, authors' calculations

\section{Determinants of FDI and Corruption}

Despite the complexity of the decision to invest abroad, UNCTAD (1998) summarizes FDI determinants in: i) economic conditions of the host country (which are different depending on the motive of the enterprise: natural resource-seeking, market-seeking, efficiency-seeking and asset-augmenting objectives);ii) government policies (policy framework towards the private sector, trade, industry and FDI); and iii) the investment strategies of Multinational Enterprises (MNE).

The main determinant FDI variables used in economic research are location or pull factors (as the size of the market and the growth rate of Gross Domestic Product (GDP)), economic stability, degree of openness of an economy, as well as several institutional variables, and push factors, relating to conditions in the source country. If FDI is a market-seeking project, the objective is to set up companies to supply goods and services to the host market. An important group of traditional economic variables, determinant of inward FDI (mainly for those who are market-oriented) is the market size of the host country, both in absolute (GDP) and relative terms (growth of GDP). When the host country market is large, the cost of distribution will be lower 
if production and distribution are near the consumer. Host countries with a larger market size, higher income per capita and faster growth allows companies to exploit their advantages. This holds true not only for market-seeking FDI projects, but also for export-oriented, because it will provide spill-over effects and economies of scale (OECD, 2000).

The empirical evidence is consistent with the hypothesis that FDI inflows react positively to the host country's market size, although the results are mixed. Several studies find a positive and significant correlation between the level of GDP and FDI (Bhasin et al, 1994; UNCTAD, 1998; Morisset, 2000; Globerman and Shapiro, 2002; Nonnenberg and Mendonça, 2004), meanwhile other researchers de not only use the level of GDP but also the growth rate to show that the level of output (or the GDP per capita) and the growth prospects play an important role in FDI attracting (Wang and Swain, 1995; UNCTAD, 1998; Agiomirgianakis et al, 2006, the last using the GDP per capita and the growth rate). Lipsey (1999) and Agiomirgianakis et al (2006) also found that higher per capita income attracts FDI inflows, while Edwards (1990) and Jaspersen et al (2000) found the effects to be negative for developing countries. Loree and Guisinger (1995), Wei (2000) and Quazi (2007) found the effects to be statistically insignificant. According to Globerman and Shapiro (2002), the GDP per capita is, in many cases, insignificant or has the wrong sign, because it also reflects the implicit wage rate (which is negatively correlated to FDI) since they are correlated to productivity levels.

Nevertheless, the UNCTAD (1996) concludes that, as a consequence of globalization and economic integration, traditional FDI determinants such as the size of national markets, has not disappeared but declined in importance. The absence of educated workers can prevent FDI inflows, because the access to a skilled workforce is essential. The location advantages of a country can be improved by policies which raise the quality of human capital. The effects of human capital on FDI inflows in the empirical literature are not consensual. Hanson (1996), Mody and Srinivasan (1998), Noorbakhsh et al (2001), Globerman and Shapiro (2002) and Agiomirgianakis et al (2006) suggest that the effects of human capital on FDI are positive. For Noorbakhsh et al (2001), human capital is not only one the most important determinants but its importance has become greater through time. But others authors found the effects to be statistically insignificant (Root and Ahmed, 1979; Schneider and Frey, 1985; Cheng and Kwan, 2000; and Quazi, 2007). For Guntlach (1995), appud in Agiomirgianakis et al (2006:7), this can be explained by the fact that education "creates externalities and spill-over effects in production, which are hard to be captured using standard sets of variables of human capital accumulation". 
Some papers, both theoretical and empirical, have pointed out the relationship between international trade and FDI. The greater the degree of openness, the larger the expected FDI flows, because more markets are available for exporters and resource allocation is more efficient, providing economic welfare gains. Nevertheless, there are mechanisms and policies that influence the relationship between these two variables, such as preferential free trade agreements and unilateral reductions in tariffs, which make that relationship complex (Ponce, 2006). Several authors found a significant positive relationship between FDI inflows and the degree of openness (Gastanaga et al,1998; Nonnenberg and Mendonça, 2004; Agiomirgianakis et al, 2006; and Mathur and Singh, 2013).

Economic instability, usually represented by the inflation rate, may inhibit inward FDI, because investors prefer to invest in economies with a lesser degree of uncertainty and in more stable economies. Negative and significant effects on FDI inflows were found by Nonnenberg and Mendonça (2004), Kahai (2004), and AlSadig (2009), despite some authors found that inflation is not statistically significant (as Ponce, 2006).

Although the effects of taxes on FDI inflow may vary by type of taxes, tax treatment in both the host and home FDI countries, and ways of addressing double taxation, it is usually admitted that higher taxes discourage FDI. Hartman's study (1984), first about this subject, suggests that certain types of FDI may not be very sensitive to taxes. More recently, De Mooij and Ederveen (2003) found a median tax-elasticity of FDI of -3.3 across 25 studies, that is, a 1 percent-point reduction in the hostcountry tax rate raises foreign direct investment in that country by 3.3 percent.

A country's economic performance over time is also determined by its political, institutional and legal environment (OECD, 2001). Political stability, developed institutions and legal systems improves its investment environment, and so, create a favourable climate for FDI, although Sethi et al (2003:318) considers that «the role of governments in providing an environment conducive to FDI cannot be overemphasized", it may also be very important in attracting FDI. Governance consists on the "traditions and institutions by which authority is exercised in a country" (World Bank, 2007, p. 2), involving political, institutional and economic reforms. Good governance enables a responsible resources management with the objective of economic growth, social development, and reducing inequalities. A stable political and economic environment, an efficient rule of law, sound infrastructures creates better conditions for investment, namely foreign. According to Barro (1991), political instability creates an uncertain economic environment, which 
has a negative impact in long-term planning, and thus, reduces economic growth and investment opportunities.

Several authors show empirical evidence that political, institutional and legal environments are important to explain differences in growth and productivity among countries (Knack and Keefer, 1995; 1997; Hall and Jones, 1999; Kaufmann et al, 1999; Talbott and Roll, 2001; Globerman and Shapiro, 2002). Many studies on FDI determinants, include nowadays some variable of political environment (Mody and Srinivasan, 1998; Tuman and Emmert, 1999; Altomonte, 2000; Bevan and Estrin, 2000; Morisset ,2000; Stevens, 2000; Hess, 2004; Magnus and Fosu, 2008), although measured in different ways. As a consequence, it is difficult to generalize the results, which may present mixed conclusions. Nigh (1985), Edwards (1990), Magnus and Fosu (2008), among others, emphasized the positive effect of political stability and they have found that political instability has a significantly detrimental effect on FDI inflows. For Hess (2004), in the choice of investment locations, political instability is more important than democracy. On the contrary, other authors found the effects to be insignificant (Loree and Guisinger, 1995; Jaspersen et al, 2000; and Hanson, 1996). Globerman and Shapiro (2002)1 show that investment in governance infrastructure (its political, institutional and legal environment) attracts foreign capital, but also creates the conditions for domestic multinational corporations to emerge and invest abroad. For Mathur and Singh (2013) democracy is not so important as economic freedom, because investors want to assure that they are protected by the state but unconstrained by it.

Corruption may affect negatively the country's ability to attract foreign investment, as it works as a tax on profits (Bardhan, 1997): the costs of doing business raises and the expected investments profitability decreases. Mo (2001) believes that corruption undermines the innovators who need to deal with public services (goods with a rigid demand), becoming the main targets of corruption, and they have to pay high bribes, since they do not have established lobbies or great influence power.

There is empirical evidence that corruption has a negative impact in several important determinants of FDI as investment (Mauro, 1995; Keefer and Knack, 1996); the quality of public infrastructure (Tanzi and Davoodi, 1997), health care and education services (Gupta et al, 2000), and economic growth (Mauro, 1995, 1996;

In this study they conclude that government infrastructures are subject to diminishing returns, so that the benefits, in terms of inflows, are most pronounced for smaller and developing economies. 
Brunetti, 1997; Poirson, 1998; Li et al, 2000; Mo, 2001; Del Monte and Pagagni, 2001; Leite and Weidmann, 2002; Gyimah-Brempong, 2002; Abed and Davoodi, 2002; Méon and Sekkat, 2005; and Castro, 2008).

Some recent empirical studies provide evidence of a negative relationship between corruption and FDI inflows (Hines, 1995; Wei, 1997, 2000; Habib and Zurawicki, 2002; Voyer and Beamish, 2004; Hakkala et al, 2008; Al-Sadig, 2009; Schudel, 2010), while others fail to find any significant relationship (Wheeler and Mody, 1992;Abed and Davoodi, 2002; Akçay, 2001). Wei (2000) in a sample of forty-five host countries and fourteen source countries, for the period 1990-1991, concludes how important corruption is on FDI: he found that a tax rate rise on multinational firms has the same negative impact on FDI as a rise of the corruption level.

These contrasting results may also depend on the degree of corruption. Caetano and Caleiro (2007) and Han (2006) found that corruption is negatively correlated with FDI only in high-level corruption countries; in countries with low-levels of corruption the influence on FDI is not so evident.

\section{Sample, model and data}

The empirical research on the impact of corruption on FDI inflows is based on the following regression equation:

$$
F D I_{i, t}=c_{i, t}+\beta_{1} \operatorname{COR}_{i, t}+\sum_{i=1}^{k} \beta_{2} X_{i, t}+\sum_{i=1}^{k} \beta_{3} Y_{i, t}+\varepsilon_{i, t}
$$

Where FDI is the level of inward FDI (in logs) received by country $i$, at time period $t$, and COR is the corruption measured by the Corruption Perception Index of Transparency International. cit is a parameter specific for each country, Xit is a vector of economic factors, and Yit a vector of political factors of the country $i$, which are control variables, that is, a set of FDI determinants other than corruption. The choice of the control variables was guided by previous empirical studies on the determinants on FDI, discussed in section 3.

The Corruption Perception Index of Transparency International ranges from 0 (most corrupt) to 10 (least corrupt), so it is important to note that since higher levels reflect lower corruption, a positive estimated coefficient for corruption $\left(\beta_{1}\right)$ reflects a negative impact on FDI.

Among the economic explanatory variables of FDI inflows, we include the GDP, the average rate of GDP over the previous five years, the degree of trade openness (measured by the ratio of imports and exports on GDP), the rate of enrollment in 
secondary education as a proxy of human capital, inflation as a proxy for economic instability, labor productivity and the highest marginal tax rate on corporate. It is also considered the political stability and absence of violence/terrorism, business freedom, rule of law and government effectiveness (see Appendix for data source and definition of the variables). The panel is composed of 73 countries, which include emerging markets, developing and developed economies, over the period 1998-2008. The sample size was constrained by the lack of data availability, but the total number of observations varies between 454 and 764, which is sufficient to produce robust estimates.

\section{Econometric results and analysis}

Table 2 reports the results of the Fixed Effects GLS regression that investigates whether corruption is a significant determinant of FDI inflows or not.

The corruption coefficients are statistically significant in all regressions and with a positive sign: the results suggest a negative impact of corruption on FDI. When controlling for several variables, the main result doesn't change, as the coefficient of corruption maintains its significance. A one point increase in the corruption level causes a reduction of FDI inflows between 0.13 and 0.245 percent.

Regressions of FDI inflows on various economic and political characteristics of the host country, suggests that the host country market size, the degree of openness, the corporate marginal tax, and political stability are significant determinants of the ability of the host country to attract FDI. Our estimates reveal that foreign investment is influenced by the market size, in terms of GDP: the coefficient on the GDP term is highly significant in all the equations, and positive. Foreign investors will focus in countries where the size of the market is large enough to guarantee the profitability of the project. However, the real growth rate is not always significant: this seems to signify that if large markets attract more FDI, "the past growths rates are apparently not projected into the future by potential investors" (UNCTAD, 1998, p. 135).

The results also suggest that markets which are more open are likely to attract foreign firms. More open economies potentially offer a more efficient allocation of resources, providing economic welfare gains. In all regressions, trade openness is statistically significant in the expected direction. Other economic factors, such as tax policy are also important determinants of FDI: a one percent point increase in the highest corporate marginal tax means a decrease of foreign direct investment between $0.025 \%$ and $0.027 \%$. As in other similar 
empirical studies, the role played by human capital, as a significant determinant of FDI inflows, is inconclusive. Other variables considered in the model, as labour productivity and inflation, do not produce conclusive results.

Business freedom, that is, a low burden of regulation that facilitate the ability to start, operate and close a business (Heritage Foundation), is a policy that promotes foreign investment. The coefficient of this variable is positive and significant at the 10 percent level. The examination of the coefficients of political stability confirms previous findings, where countries with high political stability attract more foreign investment, because it decreases uncertainty. The coefficient of government effectiveness - which evaluates the quality of public services, the capacity of the civil service and its independence from political pressures, but also the quality of policy formulation - is significant although negatively correlated with FDI inflows. 
Table 2

Regression results: panel (fixed-effects) estimations Dependent variable: Log( FDI inflows)

\begin{tabular}{|c|c|c|c|c|c|c|c|c|}
\hline & $\begin{array}{c}\text { Coefficient } \\
\text { (t-student) } \\
\text { (1) }\end{array}$ & $\begin{array}{c}\text { Coefficient } \\
\text { (t-student) } \\
\text { (2) }\end{array}$ & $\begin{array}{c}\text { Coefficient } \\
\text { (t-student) } \\
\text { (3) }\end{array}$ & $\begin{array}{c}\text { Coefficient } \\
\text { (t-student) } \\
\text { (4) }\end{array}$ & $\begin{array}{c}\text { Coefficient } \\
\text { (t-student) } \\
(5)\end{array}$ & $\begin{array}{c}\text { Coefficient } \\
\text { (t-student) } \\
(6)\end{array}$ & $\begin{array}{c}\text { Coefficient } \\
\text { (t-student) } \\
(7)\end{array}$ & $\begin{array}{c}\text { Coefficient } \\
\text { (t-student) } \\
(8)\end{array}$ \\
\hline Corruption & & $\begin{array}{c}0,17414 \star \star \star \\
(2,597506)\end{array}$ & $\mid \begin{array}{c}0,241831 \star \star \star \\
(3,021918)\end{array}$ & $\mid \begin{array}{c}0,245176 \star \star \star \\
(3,083707)\end{array}$ & $\begin{array}{c}0,200702 \star \star \star \\
(2,670364)\end{array}$ & $\begin{array}{c}0,20612 \star \star \star \star \\
(2,749532)\end{array}$ & $\begin{array}{c}0,133352 \star \star \\
(2,086374)\end{array}$ & $\begin{array}{c}0,14991 \star \\
(2,000278)\end{array}$ \\
\hline $\begin{array}{l}\text { GDP real growth } \\
\text { rate (last five years) }\end{array}$ & $\begin{array}{c}0,05282 \star \star \star \\
(3,080535)\end{array}$ & $\begin{array}{c}0,049858 \star \star \star \\
(3,036132)\end{array}$ & $\begin{array}{l}0,05545^{\star \star} \\
(2,369501)\end{array}$ & $\mid \begin{array}{c}0,068729 \star \star \star \\
(2,730191)\end{array}$ & $\begin{array}{c}0,053053 \star \star \\
(2,401271)\end{array}$ & $\begin{array}{c}0,062338 \star \star \star \\
(2,624267)\end{array}$ & $\mid \begin{array}{c}0,048306^{\star \star \star} \\
(3,072128)\end{array}$ & $\begin{array}{l}0,049516 \star \star \\
(2,225363)\end{array}$ \\
\hline $\log (\mathrm{GDP})$ & $\begin{array}{c}1,276520 \star \star \star \\
(18,70763)\end{array}$ & $\mid \begin{array}{c}1,247555 \star \star \star \\
(18,18711)\end{array}$ & $\mid \begin{array}{c}1,241162 \star \star \star \\
(13,53844)\end{array}$ & $\begin{array}{c}1,060627 \star \star \star \\
(8,484478)\end{array}$ & $\begin{array}{c}1,149634 \star \star \star \\
(12,13814)\end{array}$ & $\begin{array}{c}1,032838 \star \star \star \\
(8,328709)\end{array}$ & $\begin{array}{c}1,236956 \star \star \star \\
(16,9563)\end{array}$ & $\begin{array}{c}1,238987 \star \star \star \\
(13,28023)\end{array}$ \\
\hline $\begin{array}{l}\text { Log (real GDP } \\
\text { per capita) }\end{array}$ & & & & $\begin{array}{l}0,000079 \star \\
(1,927327)\end{array}$ & & $\begin{array}{c}0,000054 \\
(1,352182)\end{array}$ & & \\
\hline Human Capital & & & $\begin{array}{c}0,002417 \\
(0,537866)\end{array}$ & $\begin{array}{c}0,005993 \\
(1,233155)\end{array}$ & $\begin{array}{c}0,001265 \\
(0,275639)\end{array}$ & $\begin{array}{c}0,003804 \\
(0,780839)\end{array}$ & & $\begin{array}{c}0,001861 \\
(0,406874)\end{array}$ \\
\hline Trade openness & & & & & $\begin{array}{c}1,206319 \star \star \star \\
(3,729432)\end{array}$ & $\begin{array}{c}1,114640 \star \star \star \star \\
(3,424598)\end{array}$ & $\begin{array}{c}0,431982 \star \star \\
(2,168803)\end{array}$ & $\begin{array}{c}0,833561 \star \\
(2,58242)\end{array}$ \\
\hline Inflation & & & & & & & $\begin{array}{c}0,003793 \star \star \\
(2,295913)\end{array}$ & $\begin{array}{c}0,005435 \star \star \star \\
(3,554896)\end{array}$ \\
\hline \multicolumn{9}{|l|}{$\begin{array}{l}\text { Labour } \\
\text { productivity }\end{array}$} \\
\hline \multicolumn{9}{|l|}{$\begin{array}{l}\text { Highest corporate } \\
\text { marginal tax rate }\end{array}$} \\
\hline \multicolumn{9}{|l|}{ Political Stability } \\
\hline \multicolumn{9}{|l|}{$\begin{array}{l}\text { Government } \\
\text { Effectiveness }\end{array}$} \\
\hline \multicolumn{9}{|l|}{ Business Freedom } \\
\hline \multicolumn{9}{|l|}{ Rule of Law } \\
\hline R2 adjusted & 0,897 & 0,897 & 0,896 & 0,897 & 0,899 & 0,899 & 0,897 & 0,897 \\
\hline DW & 1,52 & 1,54 & 1,61 & 1,61 & 1,61 & 1,61 & 1,54 & 1,60 \\
\hline F- statistic & 6772 & 3365 & 1774 & 1339 & 1364 & 1094 & 1650 & 1060 \\
\hline $\begin{array}{l}\text { Probability } \\
\text { (F-statistic) }\end{array}$ & 0,000 & 0,000 & 0,000 & 0 & 0,000 & 0,000 & 0,000 & 0,000 \\
\hline $\begin{array}{l}\text { Number of } \\
\text { observations }\end{array}$ & 773 & 764 & 607 & 607 & 607 & 607 & 753 & 600 \\
\hline
\end{tabular}

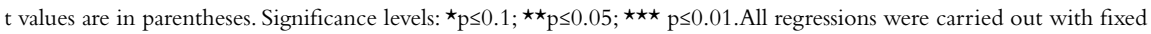
effects not reported in the table 


\begin{tabular}{|c|c|c|c|c|c|c|c|c|}
\hline $\begin{array}{c}\text { Coefficient } \\
\text { (t-student) } \\
(9)\end{array}$ & $\begin{array}{c}\text { Coefficient } \\
\text { (t-student) } \\
(10)\end{array}$ & $\begin{array}{c}\text { Coefficient } \\
\text { (t-student) } \\
\text { (11) }\end{array}$ & $\begin{array}{c}\text { Coefficient } \\
\text { (t-student) } \\
\text { (12) }\end{array}$ & $\begin{array}{c}\text { Coefficient } \\
\text { (t-student) } \\
\text { (13) }\end{array}$ & $\begin{array}{c}\text { Coefficient } \\
\text { (t-student) } \\
(14)\end{array}$ & $\begin{array}{c}\text { Coefficient } \\
\text { (t-student) } \\
(15)\end{array}$ & $\begin{array}{c}\text { Coefficient } \\
\text { (t-student) } \\
(16)\end{array}$ & $\begin{array}{c}\text { Coefficient } \\
\text { (t-student) } \\
(17)\end{array}$ \\
\hline $\begin{array}{c}0,216564 \star \star \star \\
(2,663850)\end{array}$ & $\begin{array}{c}0,181673 \star \star \\
(2,183555)\end{array}$ & $\begin{array}{l}0,148450^{\star} \\
(1,943210)\end{array}$ & $\begin{array}{c}0,211415^{\star \star} \\
(2,544062)\end{array}$ & $\mid \begin{array}{c}0,224129 \star \star \star \\
(2,717358)\end{array}$ & $\begin{array}{c}0,215795^{\star \star} \\
(2,518708)\end{array}$ & $\begin{array}{c}0,196533 \star \star \\
(1,985665)\end{array}$ & $\begin{array}{c}0,19081^{\star} \\
(1,923875)\end{array}$ & $\begin{array}{l}0,146652^{\star} \\
(1,716221)\end{array}$ \\
\hline \multirow[t]{3}{*}{$\begin{array}{c}0,105624 \star \star \star \\
(4,761075)\end{array}$} & $\begin{array}{c}0,106266^{\star \star \star} \\
(4,545588)\end{array}$ & $\begin{array}{c}0,051078 \star \star \\
(2,318047)\end{array}$ & $\begin{array}{c}0,024008 \\
(0,932969)\end{array}$ & $\begin{array}{c}0,0157 \\
(0,53544)\end{array}$ & $\begin{array}{c}0,029617 \\
(1,139264)\end{array}$ & $\begin{array}{l}0,055486^{\star} \\
(1,923746)\end{array}$ & $\begin{array}{c}0,058258^{\star \star} \\
(1,980611)\end{array}$ & $\begin{array}{c}0,037323 \\
(1,557133)\end{array}$ \\
\hline & & $\begin{array}{c}1,149333 \star \star \star \\
(8,881673)\end{array}$ & $\begin{array}{c}1,218822 \star \star \star \\
(11,80641)\end{array}$ & {$\left[\begin{array}{c}0,909681 \star \star \star \\
(4,501197)\end{array}\right.$} & $\begin{array}{c}1,075480 \star \star \star \\
(7,531178)\end{array}$ & $\begin{array}{c}0,953515 \star \star \star \\
(7,892166)\end{array}$ & $\begin{array}{c}0,936112^{\star \star \star} \\
(7,636661)\end{array}$ & $\begin{array}{c}1,155633 \star \star \star \star \\
(11,64039)\end{array}$ \\
\hline & & & & $\begin{array}{c}1,32351^{\star} \\
(1,762532)\end{array}$ & & & & \\
\hline $\begin{array}{c}0,010932 \star \star \\
(2,246701)\end{array}$ & $\begin{array}{l}0,012033 \star \\
(2,458454)\end{array}$ & $\begin{array}{c}0,001136 \\
(0,245737)\end{array}$ & $\begin{array}{l}-0,004925 \\
(-1,040259)\end{array}$ & $\begin{array}{c}-0,005994 \\
-(1,232882)\end{array}$ & $\begin{array}{c}-0,004004 \\
(-0,844403)\end{array}$ & $\begin{array}{c}0,000935 \\
(0,193524)\end{array}$ & $\begin{array}{c}0,002947 \\
(0,602759)\end{array}$ & $\begin{array}{c}-0.002498 \\
(-0,527636)\end{array}$ \\
\hline \multirow[t]{2}{*}{$\begin{array}{c}1,521836 \star \star \star \\
(4,621079)\end{array}$} & $\begin{array}{c}1,292121 \star \star \star \\
(3,780948)\end{array}$ & $\mid \begin{array}{c}0,956415 \star \star \star \\
(3,019679)\end{array}$ & $\begin{array}{c}1,445959 \star \star \star \\
(4,210576)\end{array}$ & {$\left[\begin{array}{c}1,505165 \star \star \star \\
(4,344729)\end{array}\right.$} & $\begin{array}{c}1,692417 \star \star \star \\
(4,973687)\end{array}$ & $\mid \begin{array}{c}1,059009 \star \star \star \\
(2,796196)\end{array}$ & $\mid \begin{array}{c}1,111117 \star \star \star \\
(2,883776)\end{array}$ & $\begin{array}{c}1,743197 \star \star \star \star \\
(5,479019)\end{array}$ \\
\hline & $\begin{array}{c}0,003622 \\
(1,504697)\end{array}$ & $\begin{array}{c}0,005132 \star \star \star \\
(3,255892)\end{array}$ & & & & & & \\
\hline \multirow[t]{6}{*}{$\begin{array}{c}0,00012^{\star \star \star} \\
(7,199826)\end{array}$} & $\begin{array}{c}0,000129 \star \star \star \\
(7,565061)\end{array}$ & $\begin{array}{c}1,03 \mathrm{E}-05 \\
(0,457659)\end{array}$ & & & $\begin{array}{c}2,95 \mathrm{E}-05 \\
(1,131244)\end{array}$ & & & \\
\hline & & & & & & $\begin{array}{c}-0,027192 \star \star \\
(-2,016046)\end{array}$ & $\begin{array}{c}-0,024749 \star \\
(-1,845892)\end{array}$ & \\
\hline & & & \begin{tabular}{|c|}
$0,613376^{\star \star \star}$ \\
$(4,159924)$ \\
\end{tabular} & $\begin{array}{c}0,649338^{\star \star \star} \\
(4,321856) \\
\end{array}$ & $\begin{array}{c}0,71571^{\star \star \star} \\
(4,639508) \\
\end{array}$ & & & $\begin{array}{c}0,420715 \star \star \star \star \\
(2,681413) \\
\end{array}$ \\
\hline & & & $\begin{array}{l}-0,45394 \star \star \\
(-2,130999)\end{array}$ & & & & & \\
\hline & & & & & & & $\begin{array}{l}0,007494^{\star} \\
(1,710781) \\
\end{array}$ & $\begin{array}{c}0.004162 \\
(0,821938) \\
\end{array}$ \\
\hline & & & & & & & & $\begin{array}{c}0,925475^{\star \star \star} \\
(3,623209) \\
\end{array}$ \\
\hline 0,887 & 0,882 & 0,896 & 0,900 & 0,903 & 0,902 & 0,891 & 0,890 & 0,904 \\
\hline 1,47 & 1,44 & 1,60 & 1,64 & 1,65 & 1,72 & 1,62 & 1,63 & 1,71 \\
\hline 1131 & 854 & 816 & 730 & 763 & 705 & 826 & 680 & 662 \\
\hline 0,000 & 0,000 & 0,000 & 0 & 0 & 0 & 0,000 & 0,000 & 0,000 \\
\hline 571 & 564 & 564 & 480 & 485 & 454 & 498 & 495 & 482 \\
\hline
\end{tabular}




\section{Conclusion}

More countries are expanding abroad through FDI, and most countries are seeking to attract it due to the positive effects on their economies. FDI promotes job opportunities, income, technology transfer, human capital development, management skills and even better governance. To attract FDI a host country has to promote a favourable environment to investors. This also means transparent political institutions, that is, low corruption in order not to increase business costs.

In this research it is clear that corruption is a crucial determinant of FDI inflows. The results also suggest that the market size, tax policies, a low burden of regulations that facilitates the installment and growth of companies, and a stable political environment are important factors for foreign investors.

There has been a growing concern to combat corruption all over the world. A transparent business environment and public sector become less costly for firms, as users of public services and subjects to regulations, as well as clients for licenses and permits. In this way, countries which take effective measures to combat corruption, may attract more FDI than those who do not.

In this article we studied the impact of corruption on FDI, assuming a linear relationship. In light of some studies on the impact of corruption on economic growth (Okad et al, 2010; Castro, 2008; Mendéz and Sepúlveda, 2006), it would be important for future research to establish whether there may be a nonlinear relationship, that is, if the FDI inflow may be higher for cases with low levels of corruption but detrimental for those with high levels and, therefore, determining the critical level of corruption which maximizes the level of FDI.

\section{References}

Abed, G. T. and Davoodi, H. (2002): "Corruption, Structural Reforms, and Economic Performance in the Transition Economies", in Abed, George T. and Gupta, Sanjeev (Ed.): Governance, Corruption, \& Economic Performance, International Monetary Fund, Publication Services, Washington, D.C., pp. 489-537.

Agiomirgianakis, G., Asteriou, D. and Papathoma (2006): "Determinants of Foreign Direct Investment:A panel data study for the OECD Countries”, City University, Department of Economics, Discussion Paper Series No. 3/2006

Akçay, S. (2001). “Is Corruption an Obstacle for Foreign Investors in Developing Countries? A Cross-Country Evidence”,Yapi Kredi Economic Review,Vol. 12, c 2, pp. 27-34 
Al-Sadig, A. (2009). “The Effects of Corruption on FDI Inflows, Cato Journal,Vol. 29, No. 2 (Spring/Summer), pp. 267-294

Altomonte, C. (2000). "Economic determinants and institutional frameworks: FDI in economies in transition", Transnational Corporations, Vol. 9, No. 2, pp. 75-106

Bardhan, P. (1997). "Corruption and Development:A Review of Issues”, Journal of Economic Literature,Vol. XXXV, pp. 1320-1346

Barro, R. (1991). "Economic Growth in Cross Section of Countries," Quarterly Journal of Economics, Vol. 106, No. 2, pp. 407-444

Bevan, A., and Estrin, S., (2000). "The determinants of foreign direct investment in transition economies", Centre for New and Emerging Markets, Discussion Paper Number No. 9 , London Business School, London.

Bhasin, A., Jun, K., and Economou, P. (1994), “Assessing the Sustainability of Foreign Direct Investment Flows”, World Bank, International Economics Department

Brunetti, A. (1997). "Political Variables in Cross-Country Growth Analysis", Journal of Economic Surveys, Vol. 11, No. 2, pp. 163-190

Caetano, J. and Caleiro, A. (2007). "Corruption and foreign direct investment: what kind of relationship is there?”, in Gupta, R. and Mishra S.S. (eds.), The Causes and Combating Strategies, ICFAI Books, pp. 56-72

Castro, Conceição (2008) "Corrupção e crescimento económico na União Europeia dos 15 - Determinação do nível de corrupção crítico”, Fiscalidade - Revista de Direito e Gestão Fiscal, No. 33, pp. 111- 127.

Cheng, L. K., and Kwan,Y. K. (2000). "What Are the Determinants of the Location of FDI? The Chinese Experience", Journal of International Economics,Vol. 51, No. 2, pp. 379-400

De Mooij, R. A. and Ederveen, S. (2003). "Taxation and Foreign Direct Investment: A Synthesis of Empirical Research," International Tax and Public Finance, Vol. 10, No. 6, pp. 673-93

Del Monte,A. and Pagagni, E. (2001). "Public expenditure, Corruption and Economic Growth: the Case of Italy", European Journal of Political Economy,Vol. 17, No. 1, pp. 1-16

Dunning, J. H. (2003). "Determinants of Foreign Direct Investment: Globalization-Induced Changes and the Role of Policies", Annual World Bank Conference on Development Economics, Europe, "Toward Pro-Poor Policies Aid, Institutions, and Globalization. Edited by Bertil Tungodden, Nicholas Stern, and Ivar Kolstad, pp. 279-290

Edwards, S. (1990). "Capital Flows, Foreign Direct Investment, and Debt-Equity Swaps in Developing Countries”, NBER Working Paper No. 3497 
Gastanaga, V., Nugent, J. and Pashamiova, B. (1998). "Host Country Reforms and FDI Inflows: How Much Difference Do They Make?” World Development, Vol. 26, No. 7, pp. $1299-1314$

Globerman, S. and Shapiro, D. (2002). "Global Foreign Direct Investment Flows:The Role of Governance Infrastructure”, World Development Vol. 30, No. 11, pp. 1899-1919

Guntlach, E. (1995). "The Role of Human Capital in Economic Growth: New Results and Alternative Interpretations", Weltwirtschaftliches Archiv, 131, pp. 383-402. In Agiomirgianakis, G., Asteriou, D. and Papathoma (2006). "Determinants of Foreign Direct Investment: A panel data study for the OECD Countries", City University, Department of Economics, Discussion Paper Series No. 3/2006

Gupta, S., Davoodi, H., and Tiongson, E. (2000). "Corruption and the Provision of Health Care and Education Services”, IMF Working Paper No. 116. Washington: International Monetary Fund.

Gyimah-Brempong, K. (2002). "Corruption, Economic Growth, and Income Inequality in Africa", Economics of Governance, Vol. 3, No. 3, pp. 183-209

Habib, M., and Zurawicki, L. (2002). "Corruption and Foreign Direct Investment”, Journal of International Business Studies, Vol. 33, No. 2, pp. 291-307

Hakkala, K., Norbäck, P. and Svaleryd, H. (2008). "Asymmetric Effects of Corruption on FDI: Evidence from Swedish Multinational Firms", The Review of Economics and Statistics, Vol 90, No. 4 (07), pp. 627-642

Hall, R., and Jones, C. I. (1999). "Why do some countries produce so much more output per worker than others". Quarterly Journal of Economics, Vol. 114, No. 1, pp. 83-86.

Han, K. , (2006). "Corruption and Foreign Direct Investment", Paper presented at the annual meeting of the International Studies Association, Town \& Country Resort and Convention Center, San Diego, California, USA

Hanson, J. (1996) "Human Capital and Direct Investment in Poor Countries," Explorations in Economic History,Vol. 33, pp. 86-106

Hartman, D. G. (1984). “Tax Policy and Foreign Direct Investment in the United States”, National Tax Journal,Vol. 37, No. 4, pp. 475-87

Hess, M. L., (2004). "Foreign Direct Investment and Political Stability: Why Investors Like Democracy... and Stable Autocratic States" Paper presented at the annual meeting of the The Midwest Political Science Association, Palmer House Hilton, Chicago, Illinois Online <.PDF>.2009-05-26 from http://www.allacademic.com/meta/p83662_index.html

Hines, J. R. (1995). "Forbidden Payment: Foreign Bribery and American Business After 1977”, NBER Working Paper No. 5266 
Jaspersen, F., Aylward, A. and Knox, A. (2000). "The Effects of Risk on Private Investment: Africa Compared with Other Developing Areas," in P. Collier and C. Pattillo (Eds.), Investment and Risk in Africa, New York: St. Martin's Press, pp. 71-95

Kahai, S. (2004).'Traditional And Non-Traditional Determinants of Foreign Direct Investment in Developing Countries", Journal of Applied Business Research, Vol. 20, No. 1 , pp. $43-50$

Kaufmann, D., Kraay, A., and Zoido-Lobaton, P. (1999). “Governance matters”, World Bank Working Paper No. 2196, available at: http://www.worldbank.org/wbi/governance.

Kaufmann, D., Kraay, A., and Mastruzzi, M. (2009). "Governance Matters VIII: Governance Indicators for 1996-2008”. World Bank Policy Research June 2009 Worldwide Governance indicators, WorldBank

Keefer, P., and Knack, S. (1996).'Institutions and Economic Performance: Cross-Country Tests Using Alternative Institutional Measures”, Economics and Politics,VII, pp. 207-227.

Keefer, P., and Knack, S. (1997). "Why don't poor countries catch up a cross-national test of an institutional explanation”, Economic Inquiry,Vol. 35, No. 3, pp. 590-602.

Knack, S., and Keefer, P. (1995). "Institutions and economic performance: cross-country tests using alternative institutional measures”, Economics and Politics,Vol. 7, No. 3, $207-227$.

Leite, C. and Weidmann, J. (2002). "Does Mother Nature Corrupt? Natural Resources, Corruption, and Economic Growth" in: Abed, George T. and Gupta, Sanjeev (Ed.). Governance, Corruption, \& Economic Performance, International Monetary Fund, Publication Services, Washington, D.C., pp. 159-196.

Li, H., Xu, L., and Zou, H. (2000). "Corruption, Income Distribution, and Growth", Economics and Politics,Vol. 12, No. 2, pp. 155-182

Lipsey, R. (1999). "The Location and Characteristics of US Affiliates in Asia”, NBER Working Paper No. 6876.

Loree, D. and Guisinger, S. (1955). "Policy and Non-policy Determinants of US Equity Foreign Direct Investment,” Journal of Business Studies,Vol. 26, No. 2, pp. 281-299

Magnus, F. J. and Fosu, O. (2008). "Bivariate Causality Analysis between FDI Inflows and Economic Growth in Ghana", International Research Journal of Finance and Economics, Issue 15, pp. 103-112

Mathur, A. and Singh, K. (2013).'Foreign direct investment, corruption and democracy", Applied Economics, Vol 45, No. 8, pp. 991-1002

Mauro, P. (1995). “Corruption and Growth”, Quarterly Journal of Economics, Vol. 60, No. 3, pp. 681-712 
Mauro, P. (1996). "The Effects of Corruption on Growth, Investment, and Government Expenditure", International Monetary Fund, IMF Working Paper WP/96/98, Washington, D.C.

Mendéz, F. and Sepúlveda, F. (2006):"Corruption, growth and political regimes: Cross country evidence,” European Journal of Political Economy, Elsevier, 22(1), pp. 82-98.

Méon, P. and Sekkat, K. (2005). “Does Corruption Grease or Sand the Wheels of Growth?”, Public Choice,Vol. 122, No. 1/2, pp. 69-97.

Mo, P. H. (2001). "Corruption and Economic Growth”, Journal of Comparative Economics, Vol. 29, No. 1, pp. 66-79

Mody, A., and Srinivasan, K. (1998). "Japanese and US firms as foreign investors: do they march to the same tune?" Canadian Journal of Economics,Vol. 31, No.4, pp. 778-800

Morisset, J. (2000). "FDI in Africa: policies also matter", Transnational Corporations, Vol. 9, No. 2, pp. 107-126.

Nigh, D. (1985). 'The effect of political events on US direct foreign investment: a pooled time-series cross-sectional analysis', Journal of International Business Studies, Vol. 16, No. 1 , pp. 1-17

Nonnenberg, M. and Mendonça, M. (2004). “The Determinants of Direct Foreign Investment in Developing Countries” (January).

Noorbakhsh, F, Paloni, A. and Youssef, A. (2001) "Human Capital and FDI Inflows to Developing Countries: New Empirical Evidence,” World Development,Vol. 29, No. 9, pp. $1593-1610$

OECD (2000). "Main determinants and impacts of foreign direct investment on China's economy", Directorate for Financial, Fiscal and Enterprise Affairs, Working Papers on International Investment, No. 2000/4

OECD (2001). “The well-being of nations: the role of human and social capital”. OECD, Paris.

Okada, K. and Samreth, S. "How Does Corruption Influence the Effect of Foreign Direct Investment on Economic Growth?”, MPRA Paper No. 27572, available at http://mpra. ub.uni-muenchen.de/27572/1/MPRA_paper_27572.pdf

Poirson,H. (1998). "Economic Security, Private Investment, and Growth in Developing Countries", International Monetary Fund, IMF Working PaperWP/98/4, Washington D.C.

Ponce,A. (2006). “Openness and Foreign Direct Investment:The Role of Free Trade Agreements in Latin America”, Munich Personal RePEc Archive (MPRA) Paper No. 8858

Quazi, R. M. (2007). "Foreign direct investment in Latin America: a panel regression study", The international Journal of Business and Finance Research,Vol. 1, No. 1, pp. 59-67 
Root, F. and Ahmed, A. (1979). "Empirical Determinants of Manufacturing Direct Foreign Investment in Developing Countries," Economic Development and Cultural Change, Vol. 27, pp. 751-767

Schneider, F. and Frey, B. (1985). "Economic and Political Determinants of Foreign Direct Investment”, World Development,Vol. 13, No. 12, pp. 161-175

Schudel, C. J. (2010). Corruption and Foreign Direct Investment: A Dyadic Analysis of Source and Host Country Effects." Paper presented at the annual meeting of the Midwest Political Science Association 67th Annual National Conference, The Palmer House Hilton, Chicago, IL. 2010-11-11 from http://www.allacademic.com/meta/p362660_index.html

Sethi, D., Guisinger, S.E., Phelan, S.E., Berg, D. M. (2003). “Trends in foreign direct investment flows: a theoretical and empirical analysis", Journal of International Business Studies, Vol. 34, No. 4, pp. 315-326

Stevens, G.V. G. (2000). "Politics, economics and investment: explaining plant and equipment spending by US direct Investors in Argentina, Brazil and Mexico", Journal of International Money and Finance,Vol. 19, No. 2, pp. 115-135

Talbott, J. and Roll, R. W. (2001), "Why Many Developing Countries Just Aren't". The Anderson School at UCLA, Finance Working Paper No. 19-01. Available at SSRN: http://ssrn.com/abstract $=292140$ or doi:10.2139/ssrn. 292140

Tanzi, V., and Davoodi, H. (1997). "Corruption, Public Investment and Growth", IMF Working Paper No. 139. Washington: International Monetary Fund.

Transparency International (1996). "The TI Source Book 1996”. Berlin: Transparency International, 1996

Tuman, J., and Emmert, C. (1999). "Explaining Japanese foreign direct investment in Latin America, 1979-1992”, Social Science Quarterly,Vol. 80, № 3, pp. 539-555

UNCTAD (United Nations Conference on Trade and Development) (1996). "World Investment Report 1996: "Investment, Trade and International Policy Arrangements" (UNCTAD/WIR/1996).

UNCTAD (United Nations Conference on Trade and Development) (1998). "World Investment Report:Trends and Determinants". New York and Geneva.

Voyer, P., and Beamish, P. (2004). "The Effect of Corruption on Japanese Foreign Direct Investment”, Journal of Business Ethics, Vol. 50, No. 3, pp. 211-224.

Wang, Z. Q., and Swain, N. J. (1995). "The Determinants of Foreign Direct Investment in Transforming Economies: Evidence from Hungary and China”, Weltwirtschaftliches Archiv,Vol. 131, No. 2, pp. 359-82 
Wei, S. J. (1997). "Why is Corruption So Much More Taxing Than Taxes? Arbitrariness Kills", NBER Working Paper No. 6255, November

Wei, S. J. (2000). "How Taxing Is Corruption on International Investors?" Review of Economics and Statistics, Vol. 82, No. 1, pp. 1-11

Wheeler, D., and Mody,A. (1992). "International Investment Location Decisions:The Case of U.S. Firms”, Journal of International Economics, Vol. 33, No. 1-2, pp. 57-76

World Bank (2007). "A Decade of Measuring the Quality of Governance - Governance Matters 2007”, Worldwide Governance Indicators, 1996-2006.

\section{APPENDIX}

\section{List of countries (73)}

Argentina, Australia, Austria, Bangladesh, Belarus, Belgium, Bolivia, Botswana, Brazil, Egypt, El Salvador, Estonia, Finland, France, Germany, Ghana, Greece, Hungary, Iceland, Bulgaria, Cameron, Canada, Chile, China, Colombia, Costa Rica, Cote D’Ivoire, Czech Republic, Denmark, Ecuador, India, Ireland, Israel, Italy, Luxembourg, Malawi, Malaysia, Mauritius, México, Namibia, Netherlands, New Zealand, Nigeria, Norway, Japan, Jordan, Kenya, Latvia, Peru, Philippines, Poland, Portugal, Romania, Russia, Senegal, Singapore, Slovakia, South Africa, Spain, Sweden, Switzerland, Tanzania, Thailand, Tunisia, Turkey, Uganda, Ukraine, United Kingdom, United States, Venezuela,Vietnam, Zambia, Zimbabwe 
Data source and definitions

\begin{tabular}{|c|c|c|}
\hline Variable & Description & Source \\
\hline FDI Inflows & $\begin{array}{l}\text { Foreign Direct Investment (FDI) Inflows- } \\
\text { Direct investment in reporting economy } \\
\text { (FDI Inward) in Millions of Dollars }\end{array}$ & $\begin{array}{l}\text { United Nations } \\
\text { Conference on Trade } \\
\text { and Development } \\
\text { (UNCTAD) }\end{array}$ \\
\hline Corruption & $\begin{array}{l}\text { Corruption Perception Index - Scale from } \\
0 \text { to } 10: 10 \text { - very clean, } 0 \text { - highly corrupt }\end{array}$ & $\begin{array}{l}\text { Transparency } \\
\text { International }\end{array}$ \\
\hline GDP & $\begin{array}{l}\text { Gross Domestic Product - US Dollars at } \\
\text { current prices and current exchange rates } \\
\text { in millions }\end{array}$ & UNCTAD \\
\hline $\begin{array}{l}\text { Growth rate of } \\
\text { real GDP over } \\
\text { the past five years } \\
(\%)\end{array}$ & $\begin{array}{l}\text { Calculated from GDP - US Dollars } \\
\text { at constant prices (1990) and constant } \\
\text { exchange rates (1990) in millions }\end{array}$ & UNCTAD \\
\hline Human Capital & School enrollment, secondary (\% gross) & World Bank \\
\hline Trade Openness & $\begin{array}{l}\text { Exports plus Imports to GDP ratio; } \\
\text { Exports, Imports and GDP: US Dollars at } \\
\text { current prices and current exchange rates } \\
\text { in millions }\end{array}$ & UNCTAD \\
\hline Inflation (\%) & $\begin{array}{l}\text { Percentage change in the index of } \\
\text { consumer prices }\end{array}$ & $\begin{array}{l}\text { IMF,World Economic } \\
\text { Outlook Database, April } \\
2010\end{array}$ \\
\hline $\begin{array}{l}\text { Labour } \\
\text { productivity }\end{array}$ & $\begin{array}{l}\text { GDP per person employed - Constant } \\
1990 \text { Purchasing Power Parity (PPP) \$ }\end{array}$ & Worl Bank \\
\hline $\begin{array}{l}\text { Highest } \\
\text { corporate } \\
\text { marginal tax rate }\end{array}$ & $\begin{array}{l}\text { Highest marginal tax rate (corporate rate) is } \\
\text { the highest rate shown on the schedule of } \\
\text { tax rates applied to the taxable income of } \\
\text { corporations }\end{array}$ & PricewaterhouseCoopers \\
\hline Political Stability & $\begin{array}{c}\text { Political Stability \& Absence of Violence/ } \\
\text { Terrorism - about }-2.5 \text { to } 2.5 \text {, with higher } \\
\text { values corresponding to better governance } \\
\text { outcomes }\end{array}$ & Kaufmann et al (2009) \\
\hline $\begin{array}{l}\text { Government } \\
\text { Effectiveness }\end{array}$ & $\begin{array}{c}\text { Government Effectiveness }- \text { about }-2.5 \text { to } \\
2.5 \text {, with higher values corresponding to } \\
\text { better governance outcomes }\end{array}$ & Kaufmann et al (2009) \\
\hline Rule of Law & $\begin{array}{l}\text { Rule of Law - about }-2.5 \text { to } 2.5 \text {, with } \\
\text { higher values corresponding to better } \\
\text { governance outcomes }\end{array}$ & Kaufmann et al (2009) \\
\hline $\begin{array}{l}\text { Business } \\
\text { Freedom }\end{array}$ & $\begin{array}{c}\text { Business Freedom - The business freedom } \\
\text { score for each country is a number between } \\
0 \text { and } 100 \text {, with } 100 \text { equalling the freest } \\
\text { business environment }\end{array}$ & Heritage Foundation \\
\hline
\end{tabular}


